\title{
CAREER AND FAMILY: A STUDY OF WOMEN LEADERSHIP
}

\author{
Reflianto, Joni Indra Wandi \\ STIT Syekh Burhanuddin, Pariaman, Indonesia \\ E-mail: refliantomuslim@gmail.com
}

\begin{abstract}
In the industrial revolution era of 4.0, A leader is no longer referring to gender differences but rather on competence and performance. This study aimed to analyze the gender perception and its contribution to women leadership in their career and family in Surabaya. This is a quantitative study with method survey design where the data was collected by using questionnaire and ended closed interview form. Populations of this research are dualcareer marriage women in Surabaya. To confirm the quantitative results, need interview sessions with all related respondents. Samples were determined by proportional random sampling amount are 449 respondents where, 103 full career women, 205 of them as part time career and 141 of them as housewives. The results showed that there is significant contribution toward women leadership character in three career model as independent variables those are full career, part time career and family duty as reviewed from gender perception. It showed that there are correlation between women leadership character with gender perception between their career and leadership character in their family.
\end{abstract}

Keywords: gender; women leadership; career; family

Abstrak. Era revolusi industri 4.0, seorang pemimpin tidak lagi merujuk pada perbedaan gender tetapi lebih pada kompetensi dan kinerja. Penelitian ini bertujuan untuk menganalisis persepsi gender dan kontribusinya terhadap kepemimpinan perempuan dalam karier dan keluarga mereka di Surabaya. Ini adalah penelitian kuantitatif dengan metode desain survei di mana data dikumpulkan dengan menggunakan kuesioner dan mengakhiri formulir wawancara tertutup. Populasi penelitian ini adalah wanita nikah karir ganda di Surabaya. Untuk mengkonfirmasi hasil kuantitatif, perlu sesi wawancara dengan semua responden terkait. Sampel ditentukan dengan jumlah proporsional random sampling yaitu 449 responden di mana, 103 perempuan karier penuh, 205 di antaranya sebagai karier paruh waktu dan 141 di antaranya sebagai ibu rumah tangga. Hasil penelitian menunjukkan bahwa ada kontribusi yang signifikan terhadap karakter kepemimpinan perempuan dalam tiga model karir sebagai variabel independen yaitu karir penuh, karir paruh waktu dan tugas keluarga yang ditinjau dari persepsi gender. Hal ini menunjukkan bahwa ada hubungan antara karakter kepemimpinan perempuan dengan persepsi gender antara karier dan karakter kepemimpinan mereka dalam keluarga.

Kata Kunci: Gender, Kepemimpinan Wanita, Karier, Keluarga

Permalink/DOI: https://doi.org/10.15408/harkat.v15i2.13464 


\section{Introduction}

In this globalization era, the leader is no longer referring to gender differences but rather on competence and performance, particularly searching a leader for the business in the industrial revolution era of 4.0. Based on the results of a survey conducted by Accurance in the- marketeers.com says that about 60 percent of respondents in Indonesia hope have expectation to women who become a CEO or other executive positions in 2020. It is due to the tenacity leadership of the company is a key element in improving the competitiveness of companies. The survey shows that women have more capability than men.

The research result of Shaskin \& Shaskin (2011), states that from 4000 the CEO of women and men who fill out a questionnaire CEO of The Leadership Profile (TLP) found little difference between transformational leadership CEO/ Executive men and women. CEOs women tend to show respect and greater concern for others so that women leaders act differently and more effectively than men in the lead. Caliper study results are written in Female magazine in 2013, which is characteristic of women who led the team spirit, a great woman leaders tend to implement a comprehensive leadership style when it comes to solve problems or make decisions. They are more flexible, considerate, and helpful staff. Gibson (2000) suggested that most women have a dimension of behavior tend to think of their subordinates welfare and more emphasis on her interaction and facilitate her subordinates. The study, conducted by Sasmita \& Raihan (2014) states that although there are slight differences in the potential leadership among men and women, but the strengths and weaknesses of the potential leadership of them are complementary. The importance of women to change the mindset in a way more aware that she has the same opportunity to become a leader in the work place like a man.
Various studies and research began to show that the leadership of men and women did not show a significant difference. Even in some aspects of women are superior to men in the lead. But until now the women's in the top spot is still very small, it is suspected because many women who choose a career stops when they decided to take care of their household who have become liabilities.

The dynamics of career women in the professional world becomes an interesting thing to study because of the current labor force between men and women have not been balanced. Once the managerial level in number slipped to $20 \%$, leaving only $5 \%$ of women only at the level of CEO. Usually the higher position in the organization, the fewer women who shook it. Very few women are lucky to have an opportunity to climb to the top of the organization and be successful. Meanwhile, due to family reasons and flexibility of time, $72 \%$ of career women choose to stop working. In fact, $40 \%$ of them decided to come out early in her career (Sasmita and Raihan, 2014). In fact, women who hold positions of leadership in a company are able to make a significant contribution in improving corporate performance.

Gender-related issues in women's leadership become much discussed. The main task of a woman is taking care of his home life (family). But on the other hand, a woman is entitled to career and her passion to develop themselves in accordance with what she wanted. Meanwhile, due to family reasons and flexibility of time, $72 \%$ of career women choose to stop working. In fact, $40 \%$ of them decided to come out early in his career (Sasmita and Raihan, 2014). In fact, there are currently about 5 percent of women who managed to become CEO and developed the company being operated successfully.

A woman who decides to pursue a career and become a leader in a company will be faced 
with the dual role conflict. These three outstanding women described above, serving two roles at once, namely as a corporate leader and as a housewife. According to Suryadi (2004) quoted from Diansari (2006), play two roles at once indirect give impact on both women themselves and for their family environment. Women with multiple roles required to succeed in the two conflicting roles. At home they are required to play a role subordinate to (have a position under the role of her husband) to support the needs of families by taking care of her husband and children, but at work they are required to be able independent and dominant as a leader. Conflict dual role of a woman who decides to pursue a career will be resolved when she get full support from her family who understood with her desire. Therefore the family support becomes the most important critical success factor for women in achieving their success as a leader. This statement is in line with the results of the study presented by Jones \& Jones quoted from Apollo and Cahyadi (2012) state that the husband's attitude is an important factor in determining the success of a dual-career marriage. There are husbands who feel threatened, unrivaled and jealous with his wife employment status, there is no job as the wife becomes a problem, as long as she still be able to meet and serve the needs of the husband.

This problem would be interesting to investigate deeply related to the gender issues, perception and Its contribution to women leadership in their career and family by reviewing the role of women's' dual-career marriage to build their career and family that often appears the domestic conflicts in the household life. For that reason, this research become more important to uncover 1) what's the women leadership based on their career and family perspectives? 2) What's the women leadership influenced by gender perception? 3) How far the contribution of gender perception toward women's' leadership character?

\section{Literature Review}

Based on these social roles, women are typically described and expected to be more communal, relations-oriented, and nurturing than men, whereas men are believed and expected to be more agentic, assertive, and independent than women. The agentic characteristics associated with men are consistent with traditional stereotypes of leaders (Schein 1973, 2007). Role congruity theory (RCT; Eagly \& Karau, 2002) builds upon social role theory by considering the congruity between gender roles and leadership roles and proposing that people tend to have dissimilar beliefs about the characteristics of leaders and women and similar beliefs about the characteristics of leaders and men (Eagly \& Karau, 2002).

According to the theory, when occupying leadership positions, women likely encounter more disapproval than men due to perceived gender role violation (Eagly \& Karau, 2002). Yet, Eagly and Karau (2002) also proposed that perceptions of incongruity can vary depending on features of the leadership context as well as characteristics of leaders' evaluators. Indeed, Eagly et al. (1995) surveyed respondents and found that a leadership role requiring behaviors consistent with encouraging participation and open consideration was considered to be feminine, while a role requiring the ability to direct and control people was rated as masculine in nature. On the basis of this notion, we argue that RCT can also be applied to men when occupying certain leadership positions that may be seen as incongruent with the agentic characteristics associated with the male gender role. As organizations have become faster paced, globalized environments, some organizational scholars have proposed that a more feminine style of leadership is needed to emphasize the participative and open communication needed for success (e.g., Hitt, Keats, \& DeMarie, 1998; Volberda, 1998). 
Helgesen (1990) and Rosener (1995) proposed that female leaders are more inclined to fill this leadership need than men, by drawing upon characteristics they are encouraged to uphold as part of their femininity including an emphasis on cooperation rather than competition and equality rather than a supervisor-subordinate hierarchy. More recently, Koenig, Eagly, Mitchell, and Ristikari (2011) conducted a meta-analysis examining the extent to which stereotypes of leadership are culturally masculine and determined that "leadership now, more than in the past, appears to incorporate more feminine relational qualities, such as sensitivity, warmth, and understanding" ( $p$. 634). To the extent that organizations shift away from a traditional masculine view of leadership and toward a more feminine and transformational outlook, women should experience reduced prejudice, while men may be seen as more incongruent with leadership roles. We propose, based on RCT, that key aspects of the leadership context will affect the extent to which leadership roles are seen as congruent or incongruent with both male and female gender roles, which may help to explain whether men or women are seen as more effective leaders in different situations. To address these contextual moderators of gender differences in leadership effectiveness, we undertook a quantitative synthesis of studies that compared men and women on measures of leadership effectiveness

\section{Method}

This study used a survey method where the data was collected by using questionnaire and ended closed interview form. Populations of this research are 1) full career women (manager, doctor, nurse, teller in the bank, and local government civil servant), 2) part time career women (kindergarten teachers, elementary school teachers, and women with home industry) and 3) just housewife with household duties in Surabaya. To confirm the quantitative results, need interview sessions with all related respondents. Samples were determined by proportional random sampling based zone of study with sample are 449 respondents where, 205 part time career women,

141 housewife with family duties and 103 full career women.

The qualitative data in the form of documents, interviews and observations was gathered together. Interviews were conducted to identify the respondent views and perceptions towards women leadership character and its contribution for their career and family. Interviews towards Views and Perceptions of equality gender: Interviews were conducted to identify the respondent's views about their perception of gender and its contribution on their career and family.

Data analysis technique used descriptive analysis, inferential analysis, one-way ANOVA analysis and multiple regression tests. The data obtained from the achievement tests were analyzed using SPSS 15 with a significance level of $a=0,05$. The analysis of qualitative data was obtained from the interviews on the all respondent responses towards their perception about women leadership and its contribution to their career and family through content analysis. In the content analysis, the codes were combined under certain categories to make these codes meaningful.

\section{Finding and Discussion}

To answer the first question: What's the women leadership based on their career, not career and family duty perspectives showed that overall women leadership $($ Mean $=3.98, \mathrm{SD}=$ $0: 39)$, career women $($ Mean $=4: 08, S D=0.44)$, not career women, $($ Mean $=3.96, \mathrm{SD}=0: 39)$ and family duty (Mean $=3.93, \mathrm{SD}=0.34)$, like Table 1. 
Table 1. Stage of high school students' technology skills based on residence country

\begin{tabular}{lllll}
\hline $\begin{array}{l}\text { Country of } \\
\text { Residence }\end{array}$ & $\mathrm{N}$ & Mean & $\begin{array}{l}\text { Standard } \\
\text { Deviatio } \\
\mathbf{n}\end{array}$ & $\begin{array}{l}\text { Interpre } \\
\text { tation }\end{array}$ \\
\hline $\begin{array}{l}\text { Part time } \\
\text { Career } \\
\text { women }\end{array}$ & 205 & 3.96 & 0.39 & High \\
$\begin{array}{l}\text { Family duty } \\
\text { Career } \\
\text { women }\end{array}$ & 141 & 3.93 & 0.34 & Fair \\
\hline Total & 103 & 4.08 & 0.44 & High \\
\hline
\end{tabular}

Qualitative analysis to substantiate these results can be seen by interviewing session, here women shows that they already have the leadership character in their career and guiding her family. This is evidenced by the fact interview with respondents. Yes I can be a good leader by develop my career, and understand the job career and family.

Other interview found that career women have the leadership skills that they are obtained from the company. I've been learning and practicing to become a leader in a company. Results of respondents' interviews are:

Become a female leader usually lead to the family and in their career lead a company, how to grow the crops. Become a female leader, they must be get able to make balance between their career and family

Based on the analysis of instruments and interview sessions, a female leader showed that they enable to become a leader to lead the company. It means that as a female leader, they must have clever to share their time between for their family and their career.

Test of one-way ANOVA to examine the null hypothesis of $\mathrm{H}_{0}$. The result of the research showed that there significant difference of the women leadership character influenced by their role as a career women, part time career and family duty. By using one way ANOVA test also showed there is a significant difference of women leadership based on their career like Table 2
Table 2 Analysis of female leadership differences based on their career.

\begin{tabular}{lrrrrr}
\hline Sources & DK & JDK & MDK & F & Sig. P \\
Inter & Group2 & 1.386 & .693 & 4.498 & 0.012 \\
In a & Group446 & 68.716 & .154 & & \\
Total & 448 & 70.102 & & &
\end{tabular}

Significance level up to $p<0.050, D K=$ Degree of freedom, $J D K=$ Coefficient Determinant, $M D K=$ Main of Residual

Female leadership based on their location career showed significant difference F $(2,446=$ 4,498, $\mathrm{p}=0.012$ ). Therefore null hypothesis $\mathrm{H}_{0}$ was rejected. This decision means that the Female leadership based on their career is different.

Table 3 The difference of women leadership character based on career

\begin{tabular}{|c|c|c|c|c|c|}
\hline $\begin{array}{l}\text { Var } \\
\text { i } \\
\underline{\text { able }} \\
\underline{\text { s }}\end{array}$ & $\begin{array}{l}\text { (I) } \\
\text { Career }\end{array}$ & $\begin{array}{l}\text { (J) } \\
\text { Gender } \\
\text { Percepti } \\
\text { on }\end{array}$ & $\begin{array}{l}\text { Differe } \\
\text { nc } \\
\text { e of } \\
\text { mean } \\
(\mathrm{I}-\mathrm{J})\end{array}$ & $\begin{array}{l}\text { Correc } \\
t \text { ed }\end{array}$ & Sig. \\
\hline $\begin{array}{l}\text { Wo } \\
\text { me }\end{array}$ & $\begin{array}{l}\text { Family } \\
\text { Duty }\end{array}$ & Low & .0252 & .04294 & 1.000 \\
\hline $\begin{array}{l}\text { n } \\
\text { lea }\end{array}$ & & High & $.1193\left(^{*}\right)^{-}$ & .04741 & .037 \\
\hline $\begin{array}{l}\text { d } \\
\text { ersh } \\
\text { i p }\end{array}$ & $\begin{array}{l}\text { Part } \\
\text { Time } \\
\text { Career }\end{array}$ & Low & -.0252 & .04294 & 1.000 \\
\hline & & High & $.1445^{-}{ }^{-}$ & .05088 & .014 \\
\hline & Career & Low & $.1193\left(^{*}\right)$ & .04741 & .037 \\
\hline & & High & $\begin{array}{r}.1445\left(^{*}\right. \\
)\end{array}$ & .05088 & .014 \\
\hline
\end{tabular}

* Significance to the level of $\mathrm{p}<0.05$.

The result of Bonferroni post hoc test showed that there were significant differences in Female leadership character based on their career (Family duty $(\mathrm{IJ})=-1193, \mathrm{p}=0.037$ ) and a significant difference of career women leadership and family duty with mean of Difference (IJ) = $0.1445, p=0.014$. From the table 3 above can be concluded that there are significant influences between female leadership characters by gender perception. Where the career women with high 
gender perception have stronger leadership characteristic than low gender perception. Career women have linear relationship with their leadership character.

The multiple regression test result can answer the third question of the research How far the contribution of gender perception toward women's' leadership character. Table 4 showed that the decisions of Multiple Regression Analysis (Stepwise) were administered to all respondents based on gender perception in three stages of career, full career, part time career and family duty. Regression analysis do step by step "stepwise" involving seven independent variables selected are women leadership character in the company, women leadership character in the family, women leadership character in the society, women leadership character for their position, women leadership character in their college, women leadership character for their children education and women leadership character toward her husband

Only three of all variables concerning to the contribution or have significant effect ( $p$

$<0.050$ ) to the number of variants of women leadership character shown in Table 4

Table 4. Multiple Regression Analysis For Women Leadership Character That Contribute To Womens' Career And Family

\begin{tabular}{|c|c|c|c|c|c|c|c|c|}
\hline $\begin{array}{l}\text { Elements } \\
\text { of } \\
\text { learning } \\
\text { science }\end{array}$ & B & $\begin{array}{l}\text { Cor } \\
\text { rect } \\
\text { ed }\end{array}$ & $\begin{array}{l}\mathrm{Be} \\
\mathrm{ta}\end{array}$ & $\mathrm{T}$ & $\begin{array}{l}\mathrm{Si} \\
\mathrm{g}\end{array}$ & $\overline{\mathbf{r}}$ & $\begin{array}{l}\mathrm{R} \\
2\end{array}$ & $\begin{array}{l}\text { Contr } \\
\text { ibutio } \\
\mathbf{n}\end{array}$ \\
\hline $\begin{array}{l}\text { Women } \\
\text { leadershi }\end{array}$ & 0.2 & 0.0 & 0. & 5. & 0. & $\begin{array}{l}0 . \\
4\end{array}$ & 0 & 20.4 \\
\hline $\begin{array}{l}\mathrm{p} \\
\text { character } \\
\text { in the } \\
\text { family }\end{array}$ & 42 & 43 & $\begin{array}{l}2 \\
76\end{array}$ & $\begin{array}{l}6 \\
40\end{array}$ & $\begin{array}{l}0 \\
00\end{array}$ & $\begin{array}{l}52 \\
( \\
\mathrm{a}\end{array}$ & $\begin{array}{l}2 \\
0 \\
4\end{array}$ & \\
\hline $\begin{array}{l}\text { Women } \\
\text { leadershi }\end{array}$ & 0.1 & 0.0 & 0. & 3. & 0. & $\begin{array}{l}0 . \\
5\end{array}$ & 0 & 26.1 \\
\hline $\begin{array}{l}\mathrm{p} \\
\text { character } \\
\text { in the } \\
\text { society }\end{array}$ & 58 & 42 & $\begin{array}{l}1 \\
89\end{array}$ & $\begin{array}{l}7 \\
55\end{array}$ & $\begin{array}{l}0 \\
00\end{array}$ & $\begin{array}{l}11 \\
\text { ( } \\
b\end{array}$ & $\begin{array}{l}. \\
2 \\
6 \\
1\end{array}$ & \\
\hline $\begin{array}{l}\text { Women } \\
\text { leadershi }\end{array}$ & 0.1 & 0.0 & 0. & 3. & 0. & $\begin{array}{l}0 . \\
5\end{array}$ & 0 & 27.7 \\
\hline $\begin{array}{l}\mathrm{p} \\
\text { character }\end{array}$ & 65 & 52 & $\begin{array}{l}1 \\
73\end{array}$ & $\begin{array}{l}1 \\
77\end{array}$ & $\begin{array}{l}0 \\
02\end{array}$ & $\begin{array}{l}27 \\
(\end{array}$ & i & \\
\hline
\end{tabular}

\begin{tabular}{lrlll}
\hline in the & & & c & 7 \\
& & & & 7 \\
company & & & & \\
\hline Constant & 1.7 & $\mathbf{0 . 1}$ & & \\
& 50 & 72 &
\end{tabular}

Table 4 (a) Analysis of Variance

\begin{tabular}{|c|c|c|c|c|c|c|}
\hline \multirow{3}{*}{$\begin{array}{l}\text { Mo } \\
\text { d el } \\
3\end{array}$} & & \multirow{3}{*}{$\begin{array}{l}\text { Second } \\
\text { ary } \\
\text { Total } \\
19.440\end{array}$} & \multirow{3}{*}{$\frac{\text { Df }}{3}$} & \multirow{2}{*}{$\begin{array}{l}\text { Secon } \\
\text { dary } \\
\text { Mean }\end{array}$} & \multirow[b]{2}{*}{$\mathrm{F}$} & \multirow{4}{*}{$\begin{array}{l}\text { Sig. } \\
0.00 \\
0 \\
\text { (c) }\end{array}$} \\
\hline & Sour & & & & & \\
\hline & Regression & & & 6.480 & 56.9 & \\
\hline & & & & & & \\
\hline & Residual & 50.662 & 445 & 0.114 & & \\
\hline & Total & 70.102 & 448 & & & \\
\hline
\end{tabular}

According to Table 4 showed that from seven item of women leadership character, there are three contributed significantly to influence women leadership character namely Women leadership character in the company (27.7 percent), Women leadership character in the society (26.1 percent) and Women leadership character in the family (20.4 percent)

The decision of result showed the correlation between variables leadership based on career and the whole set of independent variables is 0277 (Multiple Regression). Levels of variance in the variables that significantly allied with all the independent variables can be explained by the power of the regression model that explains the value of $R^{2}$ is 27.7 percent.

The main contribution of women leadership character is supported by women experience in leading the company (Beta $=0276$, $\mathrm{t}=5.640$ and sig. $\mathrm{T}=0.000)$ and contributed as much as 20.7 percent. This situation can be shown if the learning scores of high school students increased by 0276 units.

When the two most important variables that contribute as much as 26.1 percent against women leadership character is to get support from the society (Beta $=0158, \mathrm{t}=3.755$ and sig. $\mathrm{T}=0.000)$. The Third contribution of variable to the women leadership character based on family (Beta $=0.242, \mathrm{t}=5640$ and sig. $\mathrm{P}=$ 0.000). This result means that if leadership 
scores increased by one unit also increase women leadership character in the family as many as 0.242 units in three countries observed.

Value of $r=0527$ showed that the correlation between women leadership character with gender perception the value $\mathrm{R}^{2}=0277$ ) showing the position of phase correlation and contribution or influence between the women career and their leadership character.

Through Table 4 (a) analysis of variance found that the value of $\mathrm{F}=56918(\mathrm{DK}=3$, $445)$ and significant at $\operatorname{Sig}(\mathrm{p}=0.000)<0.001$. As an explanation, the value of $R^{2}=0277$ percent refers to the overall contribution of three (3) women work in the company with strong gender perception $=27.7$, society influence with strong gender perception getting support $=26.1$ percent $=$ and family with strong gender perception $=20.4$ percent .

From the explanation of the research result showed that there is significant difference of the women leadership character and gender perception based on full career, part time career and family duty, where women with full career have higher leadership skill versus women with part time carrier. This occurs because the career women in full career have more opportunities to perform their experiments and have highleadership skills, although in the small company stage.

There is also significant contribution toward women leadership character in three career model as independent variables such as full career in the company, part time career in the society and family duty as reviewed from gender perception. The variable of full career and high gender perception can contribute the women leadership skill are 27.7 percentages. The variable of parth ime career and high gender perception is 26.1 percentages, and the variable of family duty and high gender perception is 20.4 percentages.

\section{References}

Apollo, Andi Cahyadi. 2012. Konflik Peran Ganda Perempuan Menikah yang Bekerja Ditinjau Dari Dukungan Sosial Keluarga dan Penyesuaian diri. Widya Warta. 1(02): 254-

270.

Eagly, A. H., \& Karau, S. J. (2002). Role congruity theory of prejudice toward female leaders. Psychological Review, 109, 573-598. doi: 10.1037/0033295X.109.3.573

Eagly, A. H., Karau, S. J., \& Makhijani, M. G. (1995). Gender and the effectiveness of leaders: A meta-analysis. Psychological Bulletin, 117,125-145. doi:10.1037/0033-2909.117.1.125

Everina Diansari. 2006. Hubungan Antara Konflik Peran Ganda Pada Wanita dengan Aspirasi Karier [skripsi].Yogyakarta: Universitas Islam Indonesia.

Helgesen, S. (1990). The female advantage: Women's ways of leadership. New York, NY: Doubleday.

Hitt, M. A., Keats, B. W., \& DeMarie, S. M. (1998). Navigating in the new competitive landscape: Building strategic flexibility and competitive advantage in the 21 st century. Academy of Management Executive, $12,22-42$

Koenig, A. M., Eagly, A. H., Mitchell, A. A., \& Ristikari, T. (2011). Are leader stereotypes masculine? A meta-analysis of three research paradigms. Psychological Bulletin, 137, 616-

642. doi:10.1037/a0023557

Rosener, J. B. (1995). America's competitive secret: Utilizing women as a management strategy. New York, NY: Oxford University Press.

Sashkin, Marshall, dan Molly G. shashkin. 2011. Prinsip-prinsip Kepemimpinan. Jakarta: Penerbit Erlangga. 
Jurnal Harkat : Media Komunikasi Gender, 15 (2), 2019

Sasmita, Jumiati, dan Said Raihan.2014. Volberda, H. W. (1998). Building the flexible Kepemimpinan Pria dan Wanita. Proceeding of The $6^{\text {th }}$ NCFB and Doctoral Colloqium. Riau: Repository University of firm: How to remain competitive. New York, NY: Oxford University Press Riau. Hlm 225-239. 